\title{
PEMBUATAN PENYEDAP RASA INSTAN BERBAHAN DASAR TOMAT DENGAN PENAMBAHAN JAMUR TIRAM
}

(Making instant flavoring made from tomatoes with the addition of oyster mushrooms)

\author{
Sidrat Samaun ${ }^{1^{*}}$, Rosdiani Azis ${ }^{2}$ Nur Fitriyanti Bulotio ${ }^{3}$ \\ ${ }^{1,2,3}$ Politeknik Gorontalo, Program Studi Teknologi Hasil Pertanian \\ Jl. Muchlis Rahim, Desa Panggulo Barat, Kecamatan Botupingge, \\ Kabupaten Bone Bolango, Provinsi Gorontalo, Kode Pos 96583 \\ Email: rosdiani@poligon.ac.id
}

\begin{abstract}
ABSTRAK
Tomat memiliki potensi yang cukup besar. Tomat segar maupun olahan memiliki komposisi zat gizi yang cukup lengkap dan baik. buah tomat terdiri dari 5-10\% berat kering tanpa air dan $1 \%$ kulit dan biji. Kebiasaan masyarakat dalam mengkonsumsi makanan seperti sayur dan lauk tidak lepas dari penggunaan penyedap rasa. Monosodium glutamat (MSG) merupakan garam natrium dari asam glutamat yang merupakan senyawa cita rasa, karena penambahan MSG akan membuat makanan menjadi lebih lezat. Asam glutamat bisa didapatkan dari bahan alami seperti tomat dan jamur. Adapun tujuan penelitian yakni melakukan analisis kadar air, aktifitas antioksidan, vitamin $\mathrm{C}$ dan organoleptik terhadap penyedap rasa instan berbahan dasar tomat dan jamur tiram. Hasil uji organoleptik mengunakan metode pembeda pada 35 orang panelis mampu membedakan penyedap rasa berbahan dasar tomat dengan penyedap rasa pembanding sebelum dimasukkan dalam mie instan dan setelah dimasukkan dalam mie instan, baik dari segi rasa, warna, aroma, tekstur sedangkan untuk hasil analisis kimia, kadar air memperoleh nilai rata-rata 4,09\% dengan mengunakan lama pengeringan 11 jam 30 menit dengan suhu $60^{\circ} \mathrm{C}$, uji aktifitas antioksidan 9,7\% menunjukan adanya aktifitas antioksidan, dan uji vitamin $\mathrm{C}$ dengan metode titrasi memperoleh nilai rata-rata $6,58 \%$.
\end{abstract}

Kata Kunci: Penyedap rasa; tomat; vitamin C; monosodium glutamat; jamur

\begin{abstract}
Tomatoes have considerable potential. Tomatoes fresh and processed have a fairly complete and good nutritional composition. Tomato fruit consists of 5-10\% dry weight without water and $1 \%$ skin and seeds. People's habits in consuming foods such as vegetables and side dishes cant be separated from the use of flavorings. Monosodium glutamate (MSG) is the sodium salt of glutamic acid which is a flavor compound because it will make food more delicious. Glutamic acid can be obtained from natural ingredients such as tomatoes and mushrooms. The purpose of this research were to analyze water content, antioxidant activity, vitamin C and organoleptic for instant flavoring made from tomatoes and oyster mushrooms. The results of the organoleptic test using a discriminatory method on 35 panelists were able to distinguish tomato-based flavorings with comparison flavors before being added to instant noodles and after being added to instant noodles, both in terms of taste, color, aroma, texture, while for the results of chemical analysis, levels of water obtained an average value of $4.09 \%$ by using a drying time of 11 hours 30 minutes at a temperature of $60^{\circ} \mathrm{C}, 9.7 \%$ antioxidant activity test showed the presence of antioxidant activity, and vitamin $\mathrm{C}$ test by titration method obtained an average value of $6.58 \%$.
\end{abstract}

Keywords: Flavoring; tomato; vitamin C; monosodium glutamate; mushroom 


\section{PENDAHULUAN}

Kebiasaan masyarakat dalam mengonsumsi makan seperti sayur dan lauk tidak lepas dari penggunaan penyedap rasa. Penyedap rasa dengan penambahan Monosodium Glutamat sintetik bisa di katakan aman asalkan masih dalam standar. Kandungan MSG sintetik juga terdapat pada makanan kemasan, rasa dan gurih serta asin yang kita dapatkan itu berasal dari MSG sintetik. Padahal penggunaan MSG telah di atur oleh BPOM dalam peraturan Nomor 23 Tahun 2013 tentang batas maksimum penggunaan bahan tambahan pangan penguat rasa. Karna menurut (Haq, 2015) penggunaan MSG sintesik secara berlebihan dengan waktu yang panjang dapat merugikan kesehatan di waktu mendatang. Dalam hal ini dapat menyebabkan kerusakan terhadap otak, hati, serta membuat perkembanagan otak pada anak melambat.

Monosodium glutamat (MSG) merupakan garam natrium dari asam glutamat yang merupakan senyawa cita rasa dan telah banyak dikonsumsi luas oleh seluruh dunia sebagai penguat cita rasa, karena penambahan MSG akan membuat makanan menjadi lebih lezat (Rangkuti dkk, 2012). MSG juga bisa kita dapatkan dari tanaman, salah satu tanaman yang memiliki kandungan asam glutamat yaitu tomat dan jamur. Tomat merupakan tanaman yang mangandung protein cukup tinggi. Asam glutamat yang terdapat pada tomat, tersedia alami, tidak sintesis sehingga tidak akan kontaminan dan memunculkan dampak negatif bagi tubuh manusia. Menurut Institute of Food Tecnologist, tomat mengandung glutamat $238 \mathrm{mg}$ dan glutamat bebas $140 \mathrm{mg}$.

Sedangkan dari segi potensi menurut Badan Pusat Statistik (BPS) 2016, produksi tomat di Indonesia mulai dari tahun 2010 sampai 2015 cukup melonjak tinggi, yaitu mencapai 877.801 ton. Khususnya di daerah Gorontalo masyarakat juga sudah mulai membudidayakan tomat, tepatnya di Desa Tenilo, Kecamatan Limboto, Kabupaten Gorontalo, pada Rabu 27 Mei 2020 para petani memanen tomat mereka, yang ternyata mengalami peningkatan produktivitas mencapai $60 \%$ dari pemanenan sebelumnya. Dengan potensi yang dimiliki Kabupaten Gorontalo dalam setiap panenya yang menghasilkan harga jual tomat menurun, serta banyak dari petani yang membuang tomatnya akibat banyaknya yang tidak laku. Tomat menjadi salah satu buah yang selalu digunakan dalam masakan masyarakat Gorontalo. Sehingga perlu pengolahan untuk mengawetkan serta mempertahankan tomat pada saat tidak musim panen. Saat ini sudah banyak olahan tomat yang beredaran, di antaranya 
saus tomat, jus tomat, selai tomat, kurma tomat, dan masi banyak lagi.

Jamur menurut (Widyastuti dkk, 2015) jamur tiram dapat diolah serta menjadi solusi sebagai penyedap rasa alami yang aman, karena memiliki kandungan asam glutamat yang rendah sodium dan kalium. Kandungan asam glutamat dalam jamur tiram sebanyak $21,70 \mathrm{mg} / \mathrm{g}$ berat kering. Penambahan jamur tiram sangat berpotensi untuk diolah menjadi penyedap rasa.

Sudah banyak penelitian yang mengatakan bahwa mengonsumsi MSG sintetik secara berlebihan dan terus menerus akan merugikan kesehatan di waktu mendatang, tetapi realitanya masyarakat masih banyak yang menggunakan MSG sintetik. Oleh karena itu penelitian ini dilakukan untuk memberikan alternatif baru produk penyedap rasa instan alami berbahan dasar tomat dengan penambahan jamur tiram.

\section{METODE PENELITIAN}

Prosedur penelitian yang dilakukan merupakan penelitian yang mengacu pada penelitian Azis dan Akolo. 2019, yang kemudian dimodifikasi oleh peneliti.

1. Semua bahan dicuci bersih

2. Tomat dan jamur dipotong-potong kecil

3. Tomat dan jamur ditimbang dengan perbandingan $2: 1$
4. Siapkan bumbu-bumbu yang terdiri dari lada $2,5 \%$, bawang putih $20 \%$, bawang merah $20 \%$, garam $10 \%$, dan gula $2 \%$,

5. Tomat, jamur, lada, gula, garam, bawang putih, dan bawang merah, dihaluskan mengunakan blender

6. Bahan yang sudah diblender dikeringkan dalam oven dengan suhu $60^{\circ} \mathrm{C}$ dan lama 11 jam 30 menit

7. Setelah itu dihaluskan lagi mengunakan blender

8. Diayak selanjutnya dianalisis

Diagram alir prosedur kerja dalam pembuatan penyedap rasa instan berbahan dasar tomat dengan penambahan jamur Modifikasi Azis dan Ingka (2019).

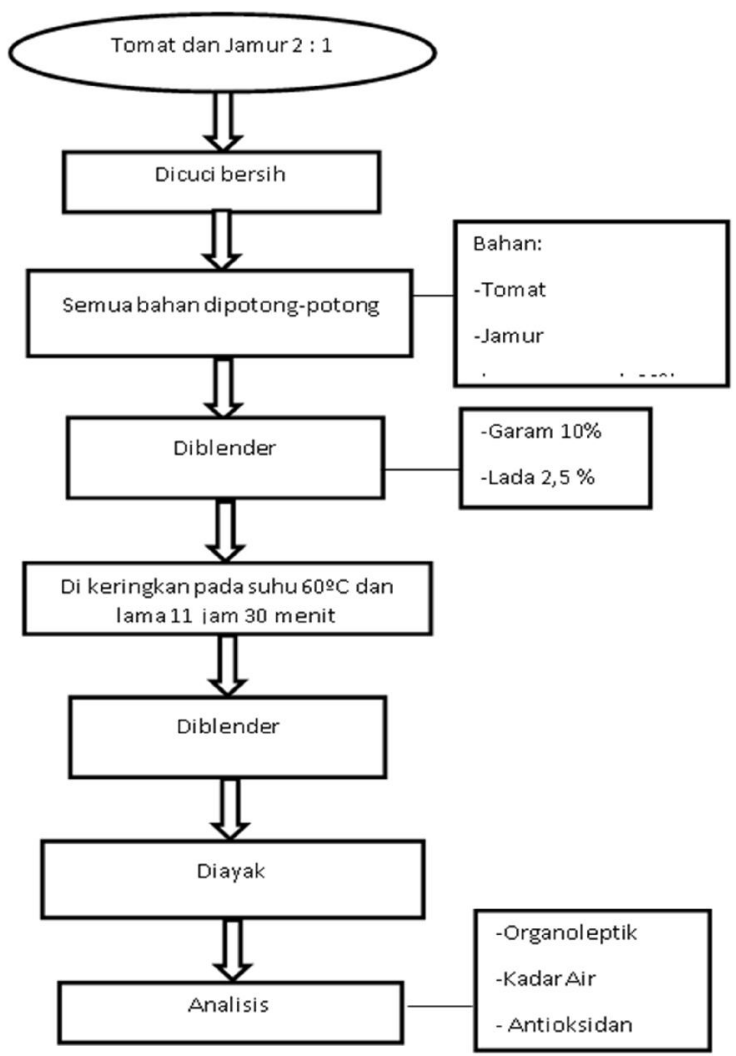


Gambar 1. Diagram pembuatan penyedap rasa instan berbahan dasar tomat dengan penambahan jamur tiram.

Parameter Pengujian

Pengamatan yang dilakukan terhadap tempe jagung pulut meliputi :

1. Uji organoleptik

2. Uji kadar air

3. Uji kadar Abu

4. Uji Vitamin C

\section{HASIL DAN PEMBAHASAN}

\section{Uji organoleptik}

\section{a. Uji Pembeda sebelum diaplikasikan dalam mie instan}

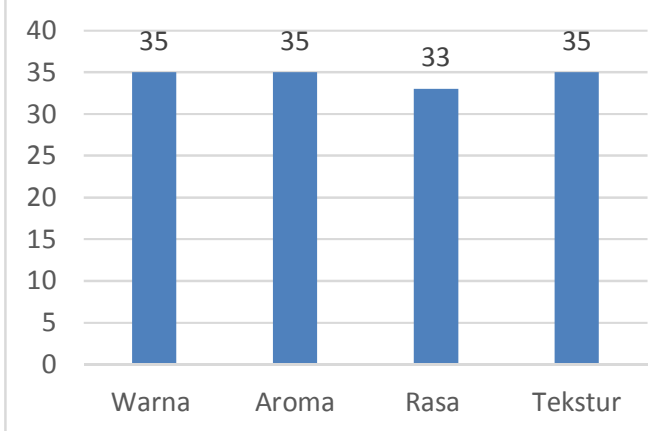

Gambar 2. Grafik hasil tingkat pembeda penyedap rasa sebelum dimasukan dalam mie instan

Uji organoleptik metode pembeda yang terdiri atas warna, aroma, rasa, dan tekstur sebelum dimasukan dalam mie instan. Adapun uji pembeda dari segi warna, aroma, rasa, tekstur :

Warna merupakan komponen yang sangat penting dalam menentukan kualitas penerimaan suatu bahan pangan. Menurut Winarno (2002), penentuan mutu bahan pangan pada umumnya sangat bergantung pada beberapa faktor, diantaranya cita rasa, warna, tekstur dan nilai gizinya. Akan tetapi faktor warna tampil lebih dulu dan sangat menentukan. Pada hasil uji pembeda pada 35 orang panelis dari tingkat perbedaan warna pada sampel sebelum dimasukan dalam mie instan terhadap penyedap rasa berbahan dasar tomat dengan penambahan jamur tiram dengan penyedap rasa pembanding menunjukan sebanyak 35 orang panelis mampu membedakannya. Hal tersebut dikarenakan pada penyedap rasa berbahan dasar tomat dengan penambahan jamur tiram lebih berwarna coklat dibandingkan dengan penyedap rasa pembanding yang warnanya putih kecoklatan. Pencoklatan yang terjadi pada penyedap rasa berbahan dasar tomat dengan penambahan jamur tiram karena adanya lama pengovenan yang mengakibatkan produk berwarna coklat. Dimana menunjukan lama pengovenan yang berpengaruh nyata terhadap warna penyedap rasa yang dihasilkan selain itu warna dari tomat merah yang kemudia dioven mengubah warna menjadi coklat.

Aroma mempunyai peranan penting dalam penentuan derajat penelitian dan kualitas suatu bahan pangan. Aroma juga bisa menjadi tolak ukur kualitas sebuah makanan Selain warna dan tekstur, bau atau aroma akan berpengaruh dan menjadi 
perhatian utama. Hasil uji perbedaan aroma sebelum dimasukan dalam mie instan pada 35 orang panelis menjukan semua panelis mampu membedakan aroma penyedap rasa berbahan dasar tomat dengan penambahan jamur tiram dan penyedap rasa pembanding. Hal ini disebabkan aroma pada penyedap rasa berbahan dasar tomat dengan penambahan jamur tiram yang aromanya khas. Dimana penyedap rasa berbahan dasar tomat dengan penambahan jamur tiram ditambahkan rempah-rempah yang telah diketahui khasiat dan manfaatnya serta mempunyai aroma sedap seperti bawang merah, bawang putih, dan lada mampu mempengaruhi aroma dari penyedap rasa (Widyastuti 2015). Sedangkan penyedap rasa pembeda aromanya lebih tajam.

Rasa adalah salah satu parameter terpenting dalam produk pangan, apakah produk ini dapat dibedakan dengan produk lain atau tidak. Dari hasil uji organoleptik metode pembeda mengunakan 35 orang panelis dapat dilihat sebanyak 35 orang mampu membedakan penyedap rasa berbahan dasar tomat dengan penamabahan jamur tiram dengan penyedap rasa pembanding. Hal ini dikarenakan penyedap rasa berbahan dasar tomat dengan penambahan jamur tiram memiliki rasa cenderung pada tomat, selain karena tomat bahan paling banyak digunakan, tomat juga memiliki rasa khas.
Sedangkan penyedap rasa pembanding memiliki rasa yang lebih asin dibandingkan penyedap rasa berbahan dasar tomat dengan penambahan jamur tiram. Karena penyedap rasa berbahan dasar tomat dengan penambahan jamur tiram rasa yang dihasilkan tidak begitu asin akibat penambahan garam yang sedikit sekitar $10 \%$.

Produk pangan pastinya memilki tekstur tersendiri tergantung dari keadaan bentuk, fisik, dan bentuknya. Penilaian dari tekstur penyedap rasa berbahan dasar tomat dengan penambahan jamur tiram dengan penyedap rasa pembanding sangat jauh berbeda, dari 35 orang panelis, semuanya mampu membedakan keduanya dari segi tekstur. Karena tekstur dari penyedap rasa berbahan dasar tomat dengan penambahan jamur tiram lebih halus, akibat 2 kali diblender, sedangkan tekstur dari penyedap rasa pembanding agak kasar dan berbentuk kristal.

\section{b. Uji pembeda setelah diaplikasikan dalam mie instan}

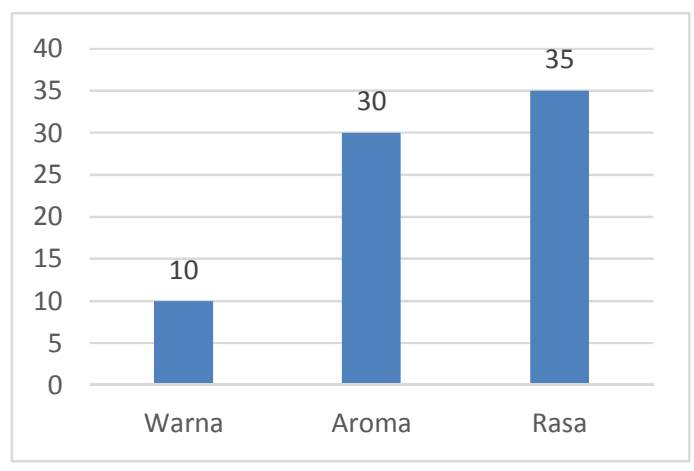


Gambar 3. Grafik hasil tingkat pembeda penyedap rasa setelah dimasukan dalam mie instan

Warna pada sampel yang telah dimasukan dalam mie instan menujukan hanya ada 10 orang panelis yang mampu membedakanya dari 35 orang panelis, ini dipengaruhi oleh warna dari mie instan setelah dimasukan peyedap rasa tidak begitu kelihatan perubahan warnanya, karena penambahan penyedap rasa dengan takaran yang sedikit tidak mempengaruhi warna dari mie instan berubah.

Aroma pada mie instan yang menujukan sebanyak 30 orang panelis mampu membedakan mie instan yang dimasukan penyedap rasa, telihat pada gambar 5. Panelis mampu membedakan aroma dari mie instan yang dimasukan penyedap rasa berbahan dasar tomat dengan peyedap rasa pembanding. Hal tersebut dipengaruhi karena bahan baku utama adalah tomat yang akhirnya memengaruhi aroma dari mie instan tersebut.

Rasa mie instan setelah dimasukan dalam mie instan jika dilihat pada gambar 5. Menunjukan sebanyak 35 Panelis mampu membedakan penyedap rasa berbahan dasar tomat dengan penambahan jamur tiram dan penyedap rasa pembanding, dikarenakan penyedap rasa berbahan dasar tomat dengan penambahan jamur tiram rasa yang dihasilkan dominan rasa tomat karena penggunaan tomat yang lebih banyak dari bahan lainya.

\section{Kadar air}

Tabel 1. Hasil analisi kadar air penyedap rasa berbahan dasar tomat dengan penambahan jamur tiram.

\begin{tabular}{ccc}
\hline No & Nama sampel & $\begin{array}{c}\text { Kadar air } \\
(\mathbf{\%})\end{array}$ \\
\hline 1 & Penyedap rasa & 4,09 \\
& berbahan dasar & \\
& tomat dengan \\
& penambahan jamur \\
& tiram & \\
& Penyedap rasa & 4 \\
& pembanding & \\
\hline
\end{tabular}

Winarno (2004) menyatakan bahwa, kadar air suatu bahan pangan mempengaruhi kenampakan, tekstur, dan cita rasa produk yang dihasilkan. Selain itu air dapat menjadi salah satu penyebab kerusakan cepat pada bahan pangan, karena air menjadi tempat berkembangnya mikroorganisme. Hasil analisis kadar air pada penyedap rasa berbahan dasar tomat dengan penambahan jamur tiram dengan menggunakan lama pengovenan selama 11 jam 30 menit dan suhu $60^{\circ} \mathrm{C}$.

Berdasarkan data tabel 5, kadar air penyedap rasa berbahan dasar tomat dengan penambahan jamur tiram berkisar 4,09\%. Sedangkan kadar air dengan penyedap rasa pembanding tidak jauh berbeda yaitu 4\% (SNI, 1996). Adapun 
rendahnya kadar air dipengaruhi oleh lama pengeringan. Menurut Sugiono (2015) semakin lama pengeringan yang dilakukan pada bahan pangan maka semakin rendah kadar air pada bahan pangan. Tingginya kadar air pada penyedap rasa berbahan dasar tomat dengan penambahan jamur tiram dipengaruhi oleh bahan pangan utama yakni tomat. Tomat memiliki kadar air yang cukup tinggi. Menurut Kailaku dkk, (2014) buah tomat mengandung kadar air $93,76 \%$ per 100 gram. Selain itu tinginya kadar air juga diakibatkan oleh tidak meratanya proses pengeringan karena wadah yang digunakan pada saat pengeringan berukuran kecil.

\section{Aktivitas antioksidan}

Tabel 2. Hasil analisis antioksidan pada penyedap rasa berbahan dasar tomat dengan penambahan jamur tiram

\begin{tabular}{ccl}
\hline Nama sampel & $\begin{array}{c}\text { Aktivitas } \\
\text { penurunan } \\
\text { absorbansi } \\
(\%)\end{array}$ & $\begin{array}{l}\text { Kandu } \\
\text { ngan } \\
\text { antioks } \\
\text { idan }\end{array}$ \\
\hline $\begin{array}{c}\text { Penyedap rasa } \\
\text { berbahan dasar } \\
\text { tomat dengan } \\
\text { penambahan } \\
\text { jamur tiram }\end{array}$ & 9.7 & Ada \\
\hline
\end{tabular}

Uji aktifitas antioksidan pada penelitian ini disebabkan oleh adanya tomat dan jamur. Berdasarkan hasil diatas peneliti hanya melakukan uji kualitatif, dimana penelitian hanya mencantumkan ada tidaknya kandungan suatu senyawa antioksidan pada produk penyedap rasa berbahan dasar dengan penambahan jamur tiram. Dari hasil diatas kita mendapatkan penurunanan absorbansi $9.7 \%$. Hal tersebut menunjukan adanya aktifitas antioksidan pada penyedap rasa berbahan dasar tomat dengan penambahan jamur tiram. Akan tetapi kita tidak mengetahui kadar antioksidanya, dan senyawa apa yang terdapat didalamnya. Adanya aktifitas antioksidan pada produk kemungkinan besar dari bahan utama yakni tomat serta jamur. Hal tersebut sesuai dengan pernyataan Munisa, (2019) tomat memiliki kandungan likopen, likopen merupakan karatenoid yang sangat dibutuhkan oleh tubuh dan merupakan salah satu antioksidan yang sangat kuat. Selain itu jamur sebagai bahan tambahan juga memiliki antioksidan, ini sesuai dengan penelitian Rhadika, (2010) ada banyak antioksidan yang terdapat disekeliling kita, salah satunya jamur tiram.

\section{Vitamin C}

Tabel 3. Hasil analisis vitamin C penyedap rasa berbahan dasar tomat dengan penambahan jamur tiram. 
Berdasarkan hasil yang pada tabel 3. Penyedap rasa berbahan dasar tomat dengan penambahan jamur tiram mendapatkan nilai rata-rata 6,58. Adanya vitamin $\mathrm{C}$ yang terdapat pada penyedap rasa berbahan dasar tomat dengan penambahan jamur tiram, karena menggunakan bahan utama yakni tomat dengan kandungan vitamin $\mathrm{C}$ yang tinggi yaitu $21 \mathrm{mg} / 100$ gram tomat (Dobrin dkk, 2019). Akan tetapi hasilnya tidak sama dengan penyedap rasa pembanding yaitu $12,40 \%$. Hal ini dipengaruhi oleh suhu dan lama pengeringan yang mampu mempengaruhi penurunan vitamin $\mathrm{C}$, pernyatan ini sesuai dengan pendapat Wastawati dan Martawati (2019) pengeringan dengan suhu diatas $30^{\circ} \mathrm{C}$ pada buah-buahan dan sayuran dapat mengakibatkan kehilangan vitamin $\mathrm{C}$ di atas $50 \%$. Selain itu menurut Kurniawati dkk., (2019) vitamin C yang mudah larut dalam air pada waktu pengirisan dan pencucian bahan juga menjadi salah satu penyebab menurunnya kadar vitamin $\mathrm{C}$.

\section{KESIMPULAN}

Kesimpulan pada penelitian adalah Hasil organoleptik mengunakan uji pembeda pada 35 orang panelis mampu membedakan penyedap rasa berbahan dasar tomat dengan penyedap rasa

\begin{tabular}{ccc}
\hline No & Nama sampel & $\begin{array}{c}\text { Vitamin } \\
\text { C (\%) }\end{array}$ \\
\hline 1 & $\begin{array}{c}\text { Penyedap rasa } \\
\text { berbahan dasar tomat } \\
\text { dengan penambahan } \\
\text { jamur tiram }\end{array}$ & 6,58 \\
2 & $\begin{array}{c}\text { Penyedap rasa } \\
\text { pembanding }\end{array}$ & 12,40 \\
\hline &
\end{tabular}

pembanding, dan adapun hasil penilaian pembeda sebelum dimasukan dalam mie instan baik dari segi rasa 30 orang, warna 35 orang, aroma 35 orang, dan tekstur 35 orang. Sedangkan hasil penilaian pembeda setelah dimasukan dalam mie instan memperoleh warna 10 orang, aroma 30 orang dan rasa 35 orang. Dan berdasarkan uji analisis kimia yang melalui beberapa parameter pengujian diperoleh nilai ratarata: kadar air yakni 4,09\%, vitamin C memperoleh nilai rata-rata $6,58 \%$, sedangkan untuk aktifitas antioksidan memperoleh nilai rata-rata $9,7 \%$ hal ini menujukan adanya aktifitas antioksidan di dalamnya

\section{DAFTAR PUSTAKA}

Azis. R, dan Akolo. I. R. 2019. Karakteristik mutu kadar air, kadar abu dan kadar organoleptik pada penyedap rasa instan. Journal of Agritech Science, Volume 3 No 2.

Badan Pusat Statistik 2016. Produksi sayuran di Indonesia. Diakses tanggal 29 November 2020.

Badan Pusat Statistik 2020. Produksi tomat di Gorontalo. Diakses pada tanggal 29 November 2020. 
Haq, N.D. 2015. Sepuluh efek bahaya MSG bagi kesehatan jangka panjang. makalah. Fakultas Ilmu Keperawatan dan Kesehatan Universitas Muhammadiyah Semarang.

Kailaku SI., Dewandari KT, dan Sunarmani. 2014. Potensi likopen dalam tomat untuk kesehatan. Buletin Teknologi Pascapanen Pertanian. vol. 3.

Kurniawati, E., Hanifa, M, R. 2019. Analisis kadar vitamin $\mathrm{C}$ pada daging buah kelengkeng kaleng dengan metode spektrofotometri. Fakultas farmsi institut ilmu kesehatan bhakti wiyati kediri.

Munisa. 2019. Analisis kadar likopen dan uji aktivitas antioksidan pada tomat asal sulawesi selatan. Jurusan biologi. Universitas negeri Makasar.

Rangkuti, R. H., Edy, S, dan Poppy, A, Z. 2012. Pengaruh pemberian monosodium glutamat (MSG) pada pembentukan mikronukleus sel darah merah mencit. Journal of Pharmaceutics and Pharmacology, 2012 Vol. 1 (1):29-36. Departemen FarmakologiFakultas Farmasi Universitas Sumatera Utara: Medan.

Rhadika. 2010. Mempelajari sifat fisik dan kimia, pleurotus $\mathrm{Sp}$ Collected Indigenously. J. Mol. Biol. Biotechnol, 1, 20-29.

Sugiyono. 2015. Metode penelitian pengaruh lama pengeringan dan suhu terhadap ikan asin asap. Bogor.

Wastawati dan Marwati. 2019. Pengaruh suhu dan lama pengeringan terhadap sifat sensoris dan sifat kimia manisan kering buah tomat. Jurnal hasil Teknologi hasil pertanian fakultas pertanian Universitas mulawarman.
Widyastuti, N., Tjokrokusumo, D, dan Giarni, R. 2015. Potensi beberapa jamur basidiomycota sebagai bumbu penyedap alternatif masa depan. (Prosiding Seminar Agroindustri dan Lokakarya Nasional FKPT-TPI. Program Studi TIP-UTM, 2-3.

Winarno F.G. 2004. Kimia pangan dan gizi. PT. Gramendia pustaka utama. Jakarta.

Winarno F.G. 2002. Teknologi fermentasi proyek pengembangan pusat fasilitasi bersama antar Universitas, PAU pangan dan gizi, UGM, Yogyakarta. 